\title{
A Comprehensive Approach to the Design of a Renewable Energy Microgrid for Rural Ethiopia: The Technical and Social Perspectives
}

\author{
Stergios Emmanouil ${ }^{1}{ }^{\circledR}$, Jason Philhower ${ }^{2}{ }^{\oplus}$, Sophie Macdonald ${ }^{3}$, Fahad Khan Khadim ${ }^{1}$, Meijian Yang ${ }^{1}{ }^{\circledR}$, \\ Ezana Atsbeha ${ }^{4}{ }^{\mathbb{D}}$, Himaja Nagireddy ${ }^{4}$, Natalie Roach ${ }^{4}$, Elizabeth Holzer ${ }^{4}$ and Emmanouil N. Anagnostou ${ }^{1, *(1)}$ \\ 1 Department of Civil and Environmental Engineering, University of Connecticut, 261 Glenbrook Road, \\ Castleman Building, Rm 313, Storrs, CT 06269, USA; stergios.emmanouil@uconn.edu (S.E.); \\ fahad.khadim@uconn.edu (F.K.K.); meijian.yang@uconn.edu (M.Y.) \\ 2 Department of Electrical and Computer Engineering, University of Connecticut, Storrs, CT 06269, USA; \\ jason.philhower@uconn.edu \\ 3 Department of Mechanical Engineering, University of Connecticut, Storrs, CT 06269, USA; \\ sophie.macdonald@uconn.edu \\ 4 Department of Sociology, University of Connecticut, Storrs, CT 06269, USA; ezana.atsbeha@uconn.edu (E.A.); \\ himaja.nagireddy@uconn.edu (H.N.); natalie.roach@uconn.edu (N.R.); elizabeth.holzer@uconn.edu (E.H.) \\ * Correspondence: manos@uconn.edu; Tel.: +1-860-486-6806
}

\section{check for} updates

Citation: Emmanouil, S.; Philhower, J.; Macdonald, S.; Khadim, F.K.; Yang, M.; Atsbeha, E.; Nagireddy, H.; Roach, N.; Holzer, E.; Anagnostou, E.N. A Comprehensive Approach to the Design of a Renewable Energy Microgrid for Rural Ethiopia: The Technical and Social Perspectives. Sustainability 2021, 13, 3974. https:// doi.org/10.3390/su13073974

Academic Editor: Catalina Rus-Casas

Received: 1 March 2021

Accepted: 30 March 2021

Published: 2 April 2021

Publisher's Note: MDPI stays neutral with regard to jurisdictional claims in published maps and institutional affiliations.

Copyright: (c) 2021 by the authors. Licensee MDPI, Basel, Switzerland. This article is an open access article distributed under the terms and conditions of the Creative Commons Attribution (CC BY) license (https:/ / creativecommons.org/licenses/by/ $4.0 /)$.
Abstract: In view of Ethiopia's significant renewable energy (RE) potential and the dynamic interactions among the components of the Water-Energy-Food (WEF) Nexus, we attempted to incorporate solar and small-scale hydropower into the optimal design of an environmentally friendly microgrid with the primary goal of ensuring the sustainability of irrigation water pumping, while taking advantage of existing infrastructure in various small administrative units (kebele). Any additional generated energy would be made available to the community for other needs, such as lighting and cooking, to support health and food security and improve the general quality of life. The novelty of the study stems from the utilization of in situ social data, retrieved during fieldwork interviews conducted in the kebele of interest, to ascertain the actual needs and habits of the local people. Based on these combined efforts, we were able to formulate a realistic energy demand plan for climatic conditions typical of Sub-Saharan Africa agricultural communities and analyze four different scenarios of the microgrid's potential functionality and capital cost, given different tolerance levels of scheduled outages. We demonstrated that the RE-based microgrid would be socially and environmentally beneficial and its capital cost sensitive to the incorporation of individual or communal machines and appliances. Ultimately, the social impact investigation revealed the design would be welcomed by the local community, whose members already implement tailor-made solutions to support their agricultural activities. Finally, we argue that extended educational programs and unambiguous policies should be in place before any implementation to ensure the venture's sustainability and functionality.

Keywords: Water-Energy-Food Nexus; microgrid; renewable energy; sustainable agriculture; social impact

\section{Highlights:}

- We employed renewable energy sources to design a microgrid for rural Ethiopia.

- We formulated a realistic energy demand plan based on social data.

- Crop security can be achieved under typical climatic conditions.

- The microgrid could enhance food and health security in the region.

- A sociological analysis reveals a positive local consensus toward the design.

\section{Introduction}

The term "Water-Energy-Food (WEF) Nexus" refers to a well-documented global interaction among water, energy, and food resources (e.g., [1,2]). Within this interaction, 
food production is by far the biggest user of global freshwater supplies, and it is likely to remain so for the rest of the century (see, e.g., [3,4]), with agriculture affecting water resources and their quality and availability through such mechanisms as land degradation and disruption of groundwater discharge $([5,6])$.

Water to support the production and consumption of edible goods is globally abundant, yet food and water insecurity are widespread (e.g., [7]). The human cost from the lack of clean water resources is high (e.g., [8]), and robust strategies are desperately needed to ensure water availability and sustainable agricultural production, toward securing human health. Furthermore, although technological advancements have increased the production of crops (e.g., $[9,10])$ and livestock (e.g., $[11,12])$ and can ultimately help developing countries meet their growing demand for food, they carry a high price in terms of energy (see, e.g., $[13,14])$ that varies based on the proximity to water resources (see, e.g., $[15,16])$.

In numerous cases (see, e.g., [17,18]), the scarcity of surface water has made the energyintensive utilization of subterranean aquifers inevitable (see [19]). Energy production, however, can have adverse effects, as mining and deforestation for fossil fuels and biofuels, respectively, reduce the available land for agriculture and damage ecosystems; and while the shift to biofuels is generally welcomed from an energy perspective, their production constitutes an arduous and time-intensive activity (see, e.g., [20,21]) with high water demands. In this regard, there is a need to transit toward renewable energy (e.g., [22,23]), which is also reflected by the United Nations (UN) Sustainable Development Goals that call for sustainable, reliable, and affordable energy sources by 2030; see also [24]. When complementing one another, variable renewable energy (VRE) sources, such as wind, solar and hydro, can provide energy sufficient to serve the needs of an entire system (e.g., [25-27]). VRE can, moreover, be employed as an off-grid solution in remote areas (see, e.g., [25]) that lack access to constant electricity for irrigation (for groundwater pumping, for example), food processing (cooking, baking, milling), and lighting. This can be accomplished through the establishment of a microgrid.

Microgrid projects incorporating VRE sources in rural areas are commonly met in the literature (e.g., [28-30]), and numerous feasibility and case studies of their use have been conducted with varying power sources and loads. The research effort by [31], in particular, was unique in its consideration of sociopolitical security with reference to the use of renewable energy technologies in Sub-Saharan Africa.

Actually, few case studies have appeared that consider the social impact of implementing renewable energy microgrids in rural communities. Refs [32,33] both studied community perceptions in Huatacondo, a rural village in northern Chile, of an off-grid renewable microgrid that incorporated a social SCADA (Supervisory Control And Data Acquisition) system to facilitate the exchange of information with the community and allow more effectively monitoring and control. In both studies, the researchers concluded that promoting learning practices for stakeholders and local residents, as a process of enhancing adaptability and reflexivity, was important in building a reliable and beneficial energy system for the community. Building upon this research, ref [34] proposed a methodology for monitoring the sustainable development of renewable energy microgrids, which supports the emergence of local policies that can ensure the continued maintenance of such systems.

The present work focuses on a few kebele, the smallest administrative units in Ethiopia, located in the Amhara state district of the country, where rural communities are dependent on off-grid lighting and heating sources ([35]). Agriculture is a major driver of the country's economy ([36]), hence the transformation of energy in this sector, especially for small stakeholder farmers, is a potentially major area for sustainable development. Due to surface water unavailability and its effects in drought periods (see, e.g., [37]), groundwater is considered a more secure water source. Still, pumping requires electricity, to which many rural communities do not have access ([38,39]).

In this regard, electrification can significantly improve farming practices in the vital area of irrigation ([40] while it can also considerably upgrade food production and preparation, as well as the general quality of life (see also [41,42]). Statistics on the distribution 
of end consumption indicate that most of the energy in rural households is utilized for cooking and lighting (see, e.g., [43]). Cooking in Ethiopia is energy and carbon intensive, since it typically involves using a mitad (i.e., a traditional wood stove), to make injera, a traditional pancake-like bread ([44]).

While rural electrification is clearly important, simply providing electricity from the main grid is overly expensive, and the cost prevents poor households from connecting to the electricity supply; see [45]. A common practice is the use of wood, biofuels, and charcoal to generate energy ([46]), which can be harmful to both humans and the environment in a variety of ways. However, there are also small-scale efforts for VRE utilization made by local communities, which were visited during a preliminary fieldwork. One example, a handmade water turbine on the Koga main canal (see Figure 1), generates sufficient electricity to provide lighting for a nearby household, despite being damaged due to its construction from low-quality materials. In the same region, an externally financed solarpowered drip irrigation system serves four farmers and covers about $40,000 \mathrm{~m}^{2}$ of avocado plots (see Figure 2), which generate profits from local sales and exports large enough not only to provide sufficient income to the farmers' families, but also to be reinvested in their agricultural practices. Such endeavors demonstrate the strong interest of the local community in benefiting from off-grid electrification. Installing larger, more durable, and efficient energy generation systems would enable the upgrading of agricultural activities, as well as provide the local community with enough power for running vital devices and appliances.

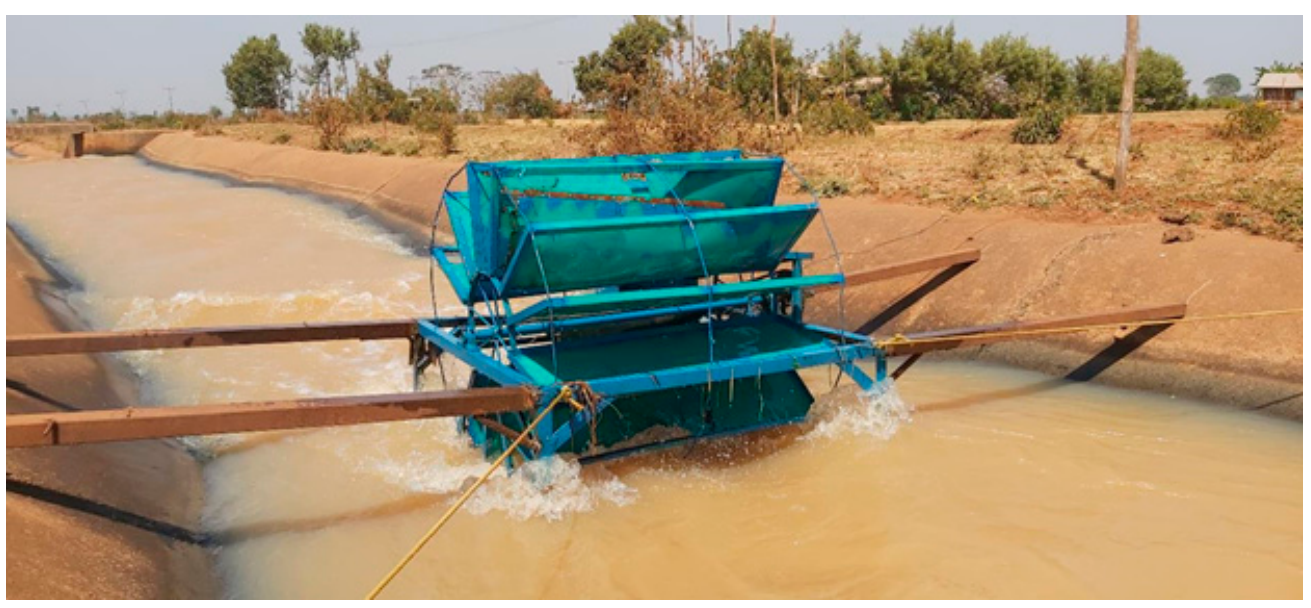

Figure 1. Water turbine (approximately $1.4 \mathrm{~kW}$ of power output) on the Koga canal located in the region surrounding the study domain.

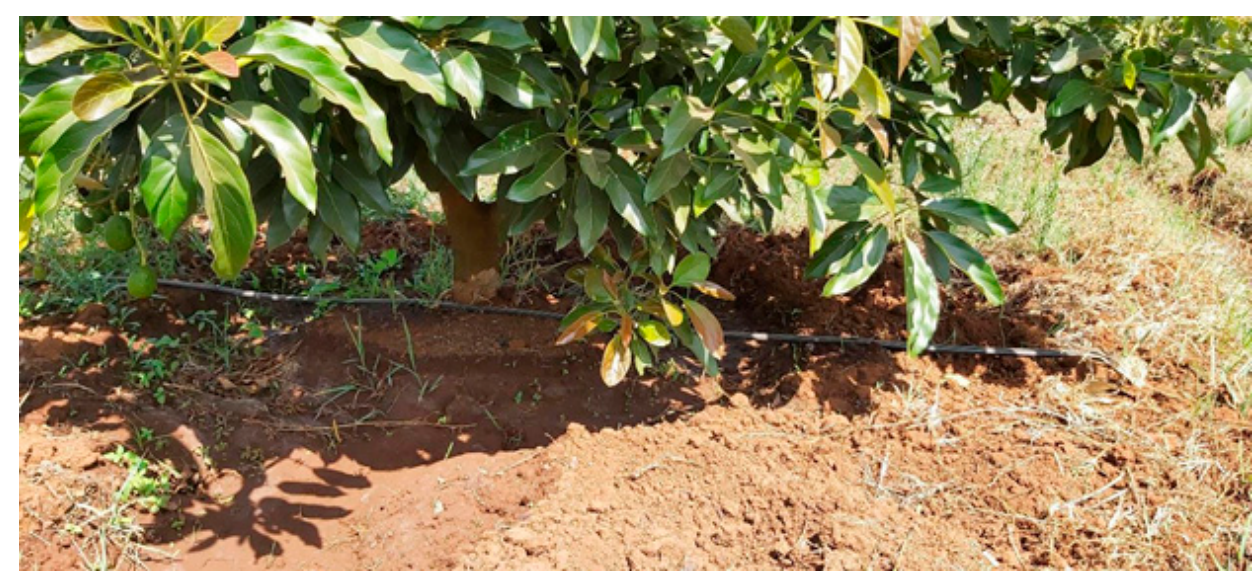

Figure 2. Solar powered drip irrigation system for avocado plants. 
In view of providing a remedy to the foregoing issues, we evaluate the potential utilization of natural energy sources (solar and hydro) and optimally design a VRE-based microgrid, while taking into account actual community needs and dynamics that were assessed during fieldwork in the study domain. The main objective is to benefit from existing water infrastructure (that is, the Koga Dam and irrigation canals) to ensure power supply primarily for irrigational water pumping. Any remaining generated energy is dedicated to other needs pertaining to lighting, cooking, and electronics (see, e.g., $[47,48]$ ). To the best of our knowledge, various studies attempted to answer similar questions independently, but we sought to holistically estimate the social impact of the VRE microgrid, by implementing a multidisciplinary framework that incorporates in situ sociological data, retrieved through research trips in the kebele under consideration, which also supported the simulation and analysis of multiple realistic operational scenarios that include different levels of energy storage and scheduled outages.

The following presents our research and its results. Section 2 provides information regarding the study domain, as well as the incorporated meteorological and sociological data. Section 3 contains the methodology and a thorough explanation of the different techniques utilized during the design of the VRE microgrid and the estimation of its social impact. Section 4 is devoted to a demonstration and discussion of the study's outcomes, while the final conclusions can be found in Section 5 .

\section{Data and Study Area}

\subsection{Study Domain: The Koga Irrigation Project}

This study was conducted over a few kebele selected from Mecha woreda (district), with emphasis on the Koga irrigation command areas. The Koga irrigation project is situated in the Upper Blue Nile basin (Northwest Ethiopia) near Merawi (the capital of Mecha), at a distance of $35 \mathrm{~km}$ from Bahir Dar and an elevation of 1829 to $2278 \mathrm{~m}$ above mean sea level. The population of the region is relatively dense (approximately 108 people $/ \mathrm{km}^{2}$ ), with an average household size of 4.3. While relatively available in town, electricity and water supply are not extended to all quarters or to farmers on the periphery. The major source of income for the inhabitants of Merawi is agriculture, with some people occupied in trade and services for the area's hotels, transportation, and restaurants.

The natural water source in the study area is the Koga River, which flows through the Koga Reservoir before pouring into the larger Gilgel Abay River ([49]); see Figure 3. Around 83 percent of the total catchment area falls in the slope range of $0-0.08$, while 14 percent is found in the range of $0.08-0.30$. The remaining 3 percent of the domain is characterized by slopes greater than 0.3 , generally located in the southern corner. During the rainy season, the area receives $70-90 \%$ of its total annual rainfall, which on average approximates $1420 \mathrm{~mm}$ /year. The average daytime temperature is $24^{\circ} \mathrm{C}$, with the hottest period starting in March and ending in May. In terms of the terrain, the majority of the downstream part of the Koga irrigation project consists of alluvial sediments (paleosol with clay), which settled there after long erosion periods of the upstream areas; see also [50]. 


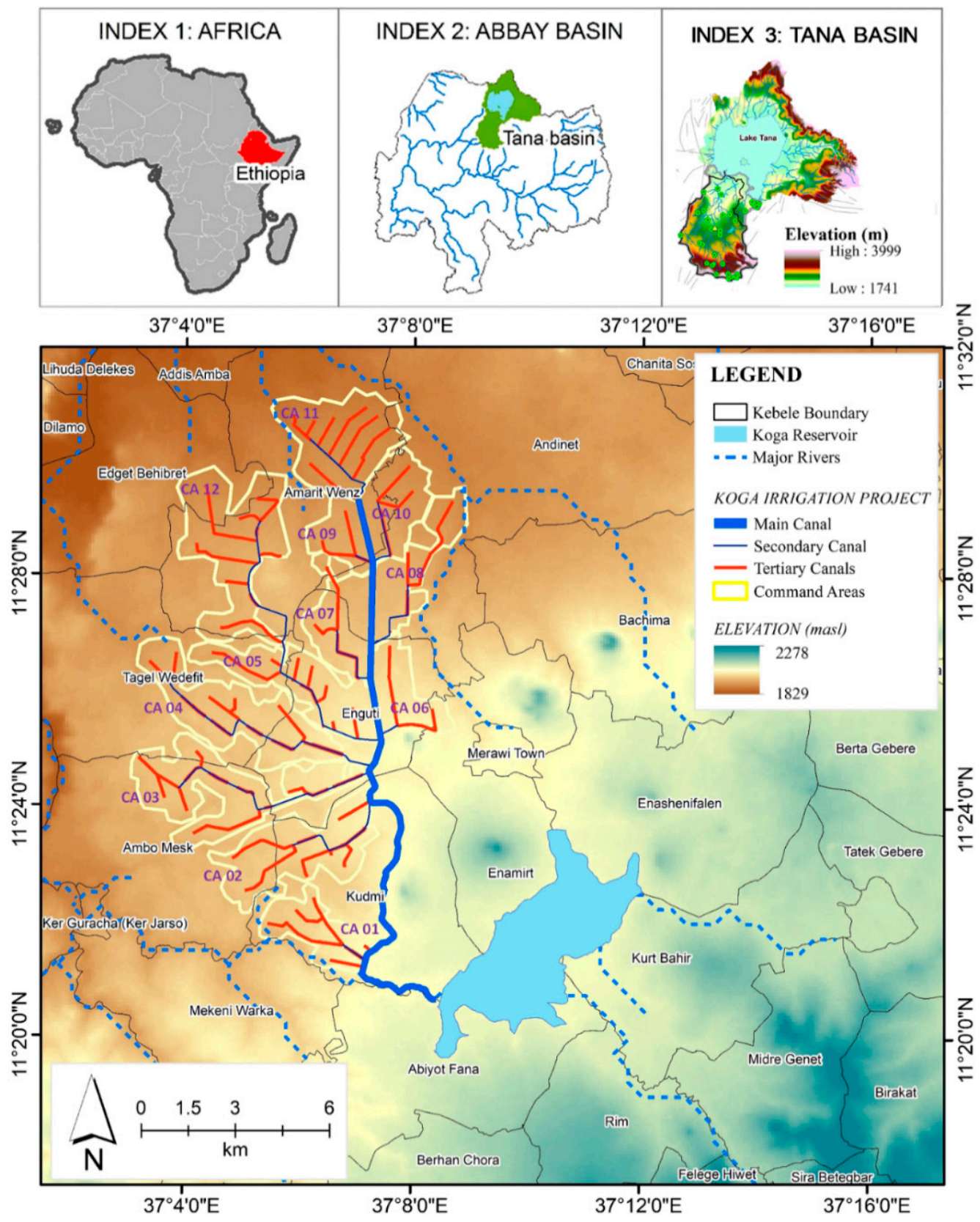

Figure 3. Overview of the study domain, showing the kebele boundaries, the topography, as well as the major rivers in the area. The Koga Reservoir, the canals of the Salient Koga Irrigation Project, and the command areas (CAs) are also featured.

\subsection{Meteorological Data}

To conduct the necessary analysis and subsequent design of the microgrid, we used the downward shortwave surface radiation (SSRD) component provided by the ERA5-Land atmospheric reanalysis dataset, which extends back to 1981 (see [51]). The aforementioned variable is the model equivalent of a pyranometer measurement and thus represents the amount of solar radiation reaching the surface of the Earth, or the so-called Global Horizontal Irradiance (GHI), which comprises both direct and diffuse solar radiation.

Generally, the uncertainty of the provided estimates grows as we go back in time, due to lack of sufficient observations to establish a good atmospheric forcing. In this regard, hourly estimates from 2000 to 2019 were employed, over a 9-km grid. We considered the spatial variation of GHI across the study domain negligible, so the dataset was spatially averaged without overlooking any valuable information. Aggregating to a daily temporal 
scale provided estimates with a mean value of $5.1 \mathrm{kWh} / \mathrm{m}^{2} /$ day, and a standard deviation of $0.9 \mathrm{kWh} / \mathrm{m}^{2} /$ day (see also Figure 4 ).

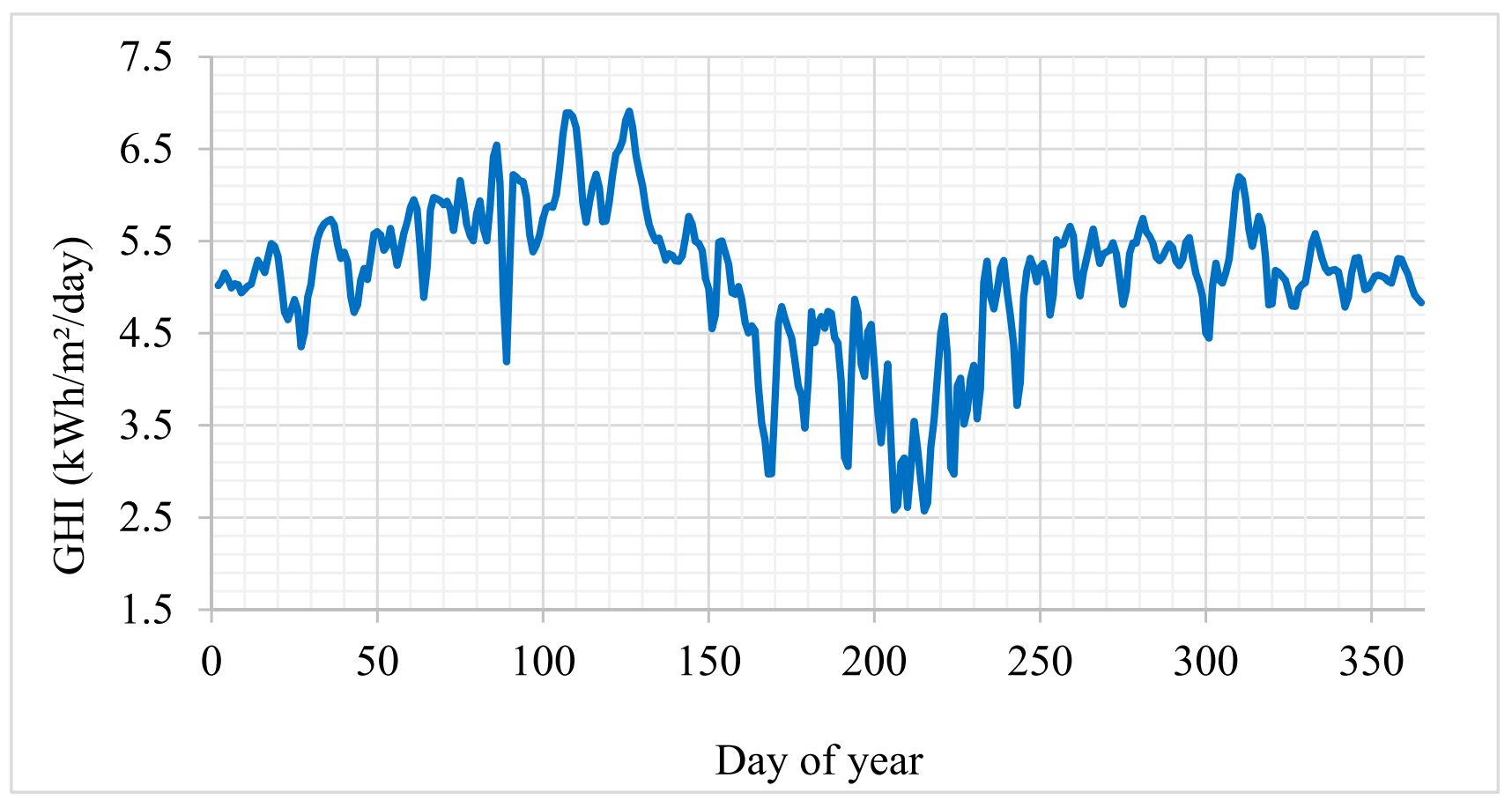

Figure 4. Average daily Global Horizontal Irradiance (GHI) over Kudmi kebele, for the time interval 2000-2019.

Along with solar irradiance, we examined the flow of irrigation canals that transfer water from the Koga Reservoir as a potential renewable energy resource. Since measurements of the actual flow velocity could not be easily obtained, we utilized simulation results for the study domain originating from the Coupled Routing and Excess STorage (CREST) distributed hydrological model; see, e.g., [52]. The model provides daily flow estimates for all waterways in the area, but, ultimately, we chose for the analysis the main irrigation canal that receives outflows directly from the Koga Reservoir, because its comparatively high flow velocities, its accessibility, and its size would all simplify the placement of hydrokinetic turbines. Note that, for modeling purposes, the main irrigation canal was considered a trapezoidal prismatic conduit, with a bottom width of $3.20 \mathrm{~m}$, a side slope of approximately $45^{\circ}$, and a maximum water discharge of $9.11 \mathrm{~m}^{3} / \mathrm{s}$ (e.g., [53]).

\subsection{Groundwater and Crop Yield}

To assess the energy required for irrigation by pumping, we used simulation results from a fine-resolution (200-m) numerical groundwater (GW) model ([54]), based on crop water demands derived from the Decision Support System for Agrotechnology Transfer (DSSAT); see also [55-58]. The study domain topography and detailed river network were generated from a 90-m Digital Elevation Model (DEM); see [59]. We collected other land and water features from digitized GIS-based information available from the Abay Basin Authority (ABA), Bahir Dar University (BU), and the Ministry of Water, Irrigation, and Energy of Ethiopia and conceptualized information on hydrogeology and aquifers based on the literature (see, e.g., [60,61]). Eventually, we forced the GW model with 11 years (corresponding to the period 2008-2019) of daily precipitation data derived from MSWEP-v1 (see [62]) and the IMERG satellite-based precipitation dataset ([63]), as well as evapotranspiration demand simulated by CREST; see [64]. As part of the groundwater model calibration, we used in situ hydraulic head and soil moisture measurements, obtained as part of a citizen science initiative (CSI) led by the University of Connecticut (UConn) and Bahir Dar University (BU) ([65]). 
As an input for DSSAT, we selected six major crops, comprising two cereals (wheat and maize) and four vegetables (potatoes, cabbages, tomatoes, and peppers), and calibrated their physiological parameters based on in situ observations. In addition, we considered avocado plants, for which we used standard irrigation requirements provided by the literature ([66]). The historical yield observations for the cereals and vegetables were retrieved from Ethiopia's Agricultural Sample Survey (AgSS); see also [67]. Finally, we collected data on the planting areas (see Table 1) for the incorporated crops from the agricultural extension office, based upon the 2018-19 irrigation season. For a detailed overview of the calibration process, see [68].

Table 1. Planting Area Coverage (ha) for different crops in 12 command areas (CA); see also Figure 3.

\begin{tabular}{ccccccccc}
\hline List & Planned & Wheat & Maize & Potato & Cabbage & Tomato & Pepper & Avocado \\
\hline CA1 & 329 & 184 & 1 & 136 & 2 & 1 & 3 & 4 \\
CA2 & 599 & 321 & 8 & 167 & 19 & 23 & 59 & 4 \\
CA3 & 696 & 594 & 22 & 34 & 20 & 1 & 16 & 9 \\
CA4 & 672 & 469 & 22 & 72 & 52 & 9 & 43 & 6 \\
CA5 & 598 & 264 & 35 & 207 & 38 & 11 & 38 & 6 \\
CA6 & 368 & 255 & 27 & 39 & 19 & 11 & 11 & 6 \\
CA7 & 477 & 315 & 18 & 95 & 24 & 4 & 16 & 6 \\
CA8 & 451 & 334 & 32 & 51 & 4 & 2 & 14 & 14 \\
CA9 & 258 & 173 & 48 & 13 & 7 & 4 & 12 & 3 \\
CA10 & 463 & 327 & 113 & 7 & 2 & 2 & 7 & 5 \\
CA11 & 787 & 473 & 95 & 194 & 2 & 7 & 13 & 4 \\
CA12 & 814 & 556 & 105 & 79 & 12 & 4 & 50 & 8 \\
Total & 6512 & 4265 & 523 & 1091 & 200 & 78 & 280 & 75 \\
\hline
\end{tabular}

\section{Models and Methods}

\subsection{Estimation of Electricity Demand and Irrigation Water Needs}

The GW model is a fine-resolution, numerical groundwater model developed using the MODFLOW-NWT program, which employs the Newton-Raphson formulation for unconfined subsurface flow conditions. The model entailed the MODFLOW Unsaturated Zone Flow package ([69]) to emphasize vadose zone flow simulations, and comprised four vertical layers (aquifers), namely, (a) a $6 \mathrm{~m}$ top soil layer underlaid by (b) a gravel-dominated fractured basalt layer of $15 \mathrm{~m}$, over (c) another fractured basalt layer of approximately $200 \mathrm{~m}$, succeeded by (d) a $4000 \mathrm{~m}$ layer of sedimentary rocks ([61,70]). The horizontal spatial resolution was $200 \mathrm{~m}$, while we used a temporal scale of $12 \mathrm{~h}$, for the time period between January 2008 and August 2019, in transient conditions.

The electricity demand was estimated based on the water stress of different crops. The latter can be defined as the interference with a plant's normal functions by a shortage of water transported and distributed through transpiration ([71]). In DSSAT, water stress is activated when the potential root water uptake (i.e., supply) is smaller or equal to the potential transpiration (i.e., demand) and is conceptualized as the ratio of the two factors ([71]). When it is active, plant growth and physiological processes are impeded. Hence, we considered a crop's water demand to be equal to the potential transpiration.

Based on this concept, we initially conducted DSSAT simulations to estimate the potential transpiration for a total of six crops: wheat, maize, potatoes, cabbages, tomatoes, and peppers. Next, we simulated the root water uptake for these crops with MODFLOW, by considering the real-field case with surface water irrigation releases and solving for the source/sink term $\frac{\partial \theta}{\partial t}$ of the 1-D Richard's equation ([69]):

$$
\frac{\partial \theta}{\partial t}=\frac{\partial}{\partial z}\left[K(\theta)\left(\frac{\partial h}{\partial z}+1\right)\right]
$$

where $K(\theta)$ denotes the hydraulic conductivity as a function of the volumetric water content, $\theta$, while $h$ is the matric head induced by capillary action, $z$ is the elevation from a reference 
level, and $t$ is the time. We considered the water deficit between the MODFLOW-simulated root water uptake and the DSSAT-simulated potential transpiration to be the volumetric quantity of water stress.

Afterwards, by using the model described by [54], we simulated groundwater pumping through artificial wells located in each of the command areas that exhibited water stress. The energy required to pump groundwater can be directly related to the dynamic water table, as well as the volume of water deficit; we used Equation (2), modified from [15], as well as the GW model estimates to calculate the daily pumping loads. Note that the use of traditional 5-horsepower motors was also considered to calculate the daily pumping duration and loads:

$$
E_{G W}=\frac{Q_{G W} g \rho H}{l_{i} l_{p} 3.6 \times 10^{6}}
$$

In Equation (2), $E_{G W}$ is the pumping energy for groundwater irrigation, $\mathrm{kWh} ; \rho$ is density of water (assumed $1000 \mathrm{~kg} \mathrm{~m}^{-3}$ ); $\mathrm{g}$ is acceleration of gravity, $\mathrm{m} \mathrm{s}^{-2} ; Q_{G W}$ is groundwater irrigation water, $\mathrm{m}^{3} /$ day; $H$ is the dynamic depth of the groundwater table, $\mathrm{m}$; and $l_{i}$ and $l_{p}$ are the losses attributed to irrigation inefficiency (conveyance loss, evapotranspiration, etc.) and pump inefficiency.

As mentioned in the preceding sections (see Section 2.3, we also explored the possibility of avocado irrigation using groundwater, taking into account the growing local interest for the plant in recent years. Given that DSSAT cannot simulate avocados by default, along with the absence of any local studies for assessing its potential transpiration, we adopted recommended irrigation values for fully grown avocado trees from studies in California (USA) ([66]). Consequently, we compared the aforementioned provided water requirements with the availability, either through irrigation or precipitation, of surface water in the fields. Then, we added the deficit to be remedied by groundwater to the water pumping electricity loads. It is important to highlight that, even though the numerical models can cover a wide range of simulation years, we only selected certain scenarios tailored to the needs of the microgrid design: a normal year (2013), a wet year (2014), and a dry year (2015).

\subsection{Microgrid Design and Capital Cost}

We designed and optimized the microgrid and estimated the total cost by means of HOMER (Hybrid Optimization of Multiple Energy Resources), a software tool widely utilized in the evaluation of off-grid and grid-connected power system designs; see, e.g., [72-74], among many others. Its simulations are founded on energy balance equations for each time step of a selected year and any possible system configuration, with the electric and thermal demand compared to the energy that can be supplied. If the system contains batteries, HOMER determines whether and when to charge or discharge them. Consequently, the flow of energy to and from each system component can be estimated. We optimized the microgrid using a proprietary, derivative-free algorithm that minimizes the cost of the system (accounting for capital, replacement, operation and maintenance, etc.), based on various parameters and constraints, such as certain limits for the excess thermal output. A predefined simulation time step was set to $60 \mathrm{~min}$.

Here, we selected the microgrid loads based on information retrieved from various fieldwork excursions and interviews in the kebele, which revealed the specifications of the most frequently utilized appliances, as well as the habits of the local people. On average, for instance, a household bakes injera every three days, with the procedure taking up to one hour, and under normal circumstances, households cook three times a day, for approximately 15-30 min. Another example, the electric plate mill, is a versatile machine that can be used to grind various grains; it requires about $0.7-1.5 \mathrm{~kW}$ for coarser grinding and 3.4-4 kW for finer; see also [75]. 
The PV array output was estimated in HOMER based on the following relationship:

$$
P_{\mathrm{PV}}=Y_{\mathrm{PV}} f_{\mathrm{PV}}\left(\frac{\overline{G_{T}}}{\overline{G_{T, S T C}}}\right)\left[1+\alpha_{P}\left(T_{\mathcal{c}}-T_{\mathcal{c}, S T C}\right)\right]
$$

where $Y_{\mathrm{PV}}$ denotes the rated capacity of the PV array (under standard test conditions), $f_{\mathrm{PV}}$

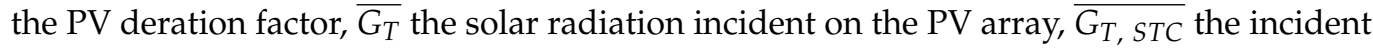
solar radiation at standard test conditions, $\alpha_{P}$ the temperature coefficient of power, and $T_{c}$ the PV cell temperature; and $T_{\mathcal{C}, ~ S T C}=25^{\circ} \mathrm{C}$, which is the PV cell temperature under standard test conditions. We calculated the temperatures based on an energy balance for the PVs, as presented in [76]:

$$
\tau \alpha G_{T}=\eta_{c} G_{T}+U_{L}\left(T_{c}-T_{\alpha}\right),
$$

with $\tau$ denoting the solar transmittance of any cover of the PV array, $\alpha$ the solar absorptance of the array, $G_{T}$ the solar radiation striking the PV array, $\eta_{c}$ the electrical conversion efficiency, $U_{L}$ the coefficient of heat transfer to the surroundings, $T_{c}$ the PV cell temperature, and $T_{\alpha}$ the ambient temperature.

As HOMER can only receive a single year as an input variable, accompanied by upper or lower confidence boundaries, certain characteristic cases for the global horizontal irradiance (GHI) are required; see also Section 2.2. We conducted a simple statistical analysis on the hourly GHI data to distinguish a baseline year, along with potential borderline scenarios (Table 2). Generally, as shown in Table 2, most years had similar statistical properties, with the exception of 2000, which displayed high solar radiation values with lower standard deviation. To encapsulate the most probable behavior of the PV array and remain on the conservative side, we avoided using 2000 as one of the scenarios studied. Instead, we selected 2019 as our baseline case and 2017 as the lower boundary, in view of their recency.

\begin{tabular}{|c|c|c|c|}
\hline Year & Mean $\left(\mathrm{kWh} / \mathrm{m}^{2}\right)$ & Standard Deviation $\left(\mathrm{kWh} / \mathrm{m}^{2}\right)$ & Coefficient of Variation \\
\hline 2000 & 5.147 & 0.821 & 0.1595 \\
\hline 2001 & 5.096 & 0.909 & 0.1785 \\
\hline 2002 & 5.097 & 0.909 & 0.1784 \\
\hline 2003 & 5.097 & 0.909 & 0.1784 \\
\hline 2004 & 5.096 & 0.908 & 0.1782 \\
\hline 2005 & 5.096 & 0.909 & 0.1785 \\
\hline 2006 & 5.097 & 0.909 & 0.1784 \\
\hline 2007 & 5.097 & 0.909 & 0.1784 \\
\hline 2008 & 5.096 & 0.908 & 0.1782 \\
\hline 2009 & 5.096 & 0.909 & 0.1785 \\
\hline 2010 & 5.097 & 0.909 & 0.1784 \\
\hline 2011 & 5.097 & 0.909 & 0.1784 \\
\hline 2012 & 5.096 & 0.908 & 0.1782 \\
\hline 2013 & 5.096 & 0.909 & 0.1785 \\
\hline 2014 & 5.097 & 0.909 & 0.1784 \\
\hline 2015 & 5.097 & 0.909 & 0.1784 \\
\hline 2016 & 5.096 & 0.908 & 0.1782 \\
\hline 2017 & 5.096 & 0.909 & 0.1785 \\
\hline 2018 & 5.097 & 0.909 & 0.1784 \\
\hline 2019 & 5.097 & 0.909 & 0.1784 \\
\hline
\end{tabular}

Table 2. Year-to-year statistics for the global horizontal irradiance (GHI) over Kudmi kebele. 
The hydrokinetic power $\left(P_{\text {hyd }}\right)$ was calculated for shallow open channels as shown in Equation (5):

$$
P_{\text {hyd }}=0.5 \eta \rho Q v^{2}
$$

where $\eta \approx 0.90$ is the efficiency of the hydrokinetic turbine and $\rho\left(1000 \mathrm{~kg} / \mathrm{m}^{3}\right)$ is the water viscosity. The water discharge $(Q)$ was provided by simulations conducted in CREST, while the stream velocity $(v)$ was calculated numerically via Manning's equation for open channel flow (Equation (6), coupled with the mass conservation relationship (Equation (7)), by means of the Newton-Raphson method:

$$
\begin{gathered}
V=\frac{1}{n}\left(\frac{A}{P}\right)^{2 / 3} S^{1 / 2}, \\
v=Q A
\end{gathered}
$$

where $n$ is Manning's roughness coefficient (0.015 for concrete canal; see [77]), $A$ is the flow area of the trapezoidal conduit, $p$ is the wetted perimeter, and $S$ is the downward slope of the irrigation canal (see also Section 2.2) For HOMER, we employed the generic $5 \mathrm{~kW}$ hydrokinetic turbine and used the flow velocities derived by Equation (6) as inputs. Note that we assumed the hydrokinetic turbines would be functioning for five hours during the wet seasons, based on information for the Koga Dam operation we retrieved during fieldwork in Kudmi.

\subsection{Social Impact Assessment}

In fieldwork conducted during February and March 2020, an Ethiopian team member held informal interviews and conversations with experts from the district's water and energy offices, as well as the agriculture office and the kebele administration, to gather information regarding off-grid energy use and demand and solar-pump irrigation in the study area. Several more interviews were conducted with three groups: users of a locally assembled water turbine, farmers who used a government-supplied solar pump for irrigation, and members of farming households. After receiving the information, we assessed the social impact of the microgrid based on a comparison with the relevant literature (see also Section 4.4).

\section{Results}

\subsection{Crop Water Stress and Supplemental Irrigation}

By retrieving the potential transpiration results from DSSAT, we estimated the water stress for the studied crops in all 12 command areas (CAs), which are defined as the domains that can be reliably irrigated from Koga Dam and its canals. Figure 5 shows the annual crop water stress (mm) for wheat crops, from the 2012-2013 to the 2018-2019 irrigation cycles, in all CAs. It is evident that 2015 was a characteristically dry year, thus the water stress was extremely high. Certainly, attempting to compensate for this high a deficit of irrigation water solely through groundwater pumping can be a considerable challenge, both in financial and environmental terms. On the other hand, the previous year (2014) was exceptionally wet, with uniformly zero requirement for pumping. For the rest of the simulated years, the water deficit was reasonable, with the groundwater model simulations indicating that the supply could be supplemented from the groundwater reserve with a sustainable decline of the groundwater table (that is, dynamic water table fluctuations within $5 \mathrm{~m}$ during pumping, which could be restored to normal by the subsequent JJAS precipitation); see also [54]. In this study, we conducted a preliminary assessment of the microgrid's functionality under normal conditions; including extremely dry (e.g., 2015) or extremely wet (e.g., 2014) years to estimate the irrigation water requirements-and the resultant electricity loads-was not, therefore, within the scope of this research effort. 


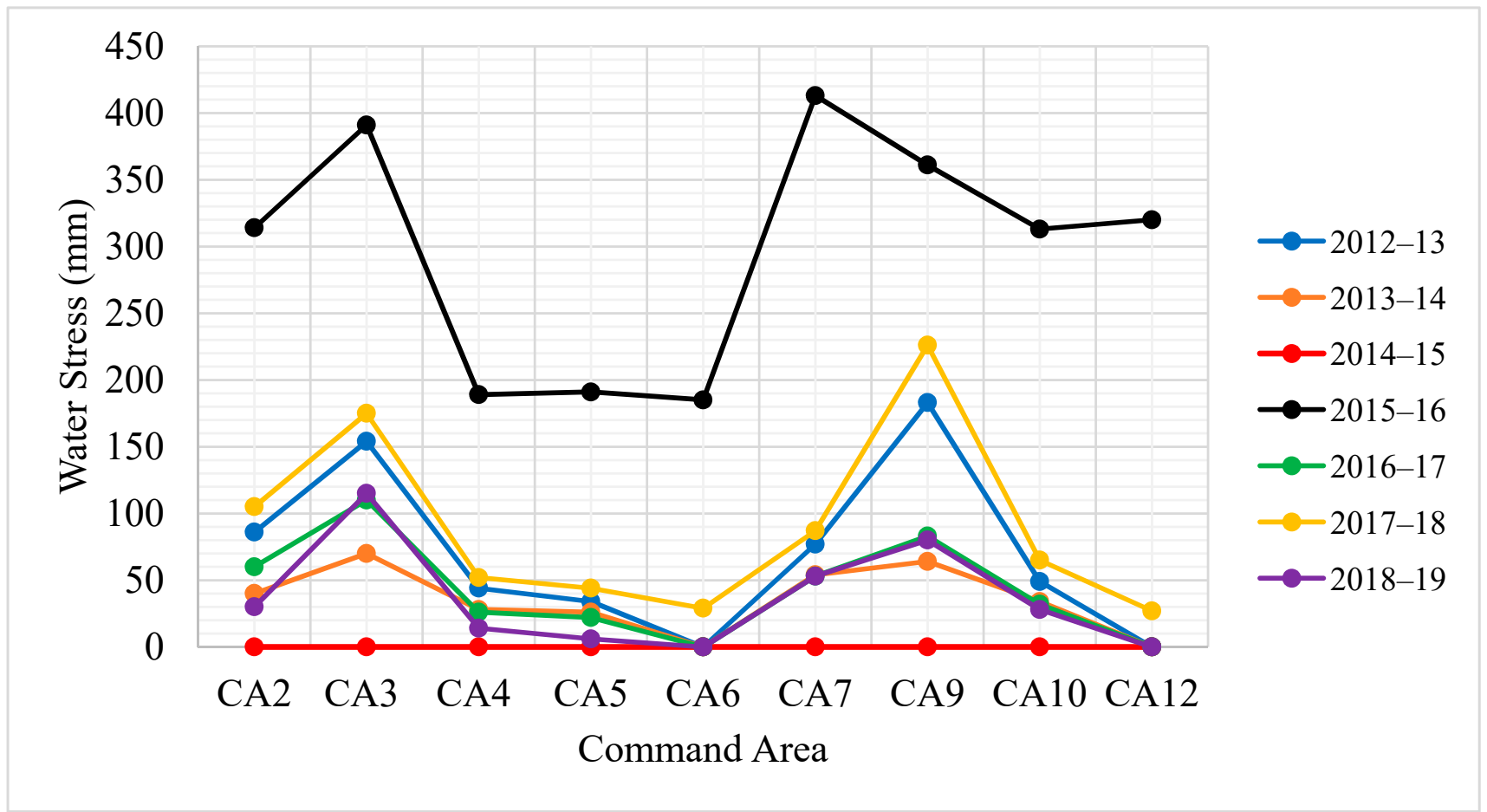

Figure 5. Annual water stress estimates $(\mathrm{mm})$ in the case of wheat crops, for all studied command areas (CA) in the time period 2012-2019.

Figure 6 shows a summary of the estimated loads of the motor pumps when utilized for irrigation. Typically, we expect the cereals to induce higher electricity loads than other crops, due to their higher water requirements and larger planting areas; see Figure $6 \mathrm{~b}$ for wheat. In support of our foregoing argument, it was evident that the loads were extremely high during the drought year (that is, the 2015-2016 irrigation cycle). Nonetheless, for time periods with typical conditions, such as the 2012-2013 irrigation cycle, the supplemental water requirements were generally low (see also Figures 5 and 6a).
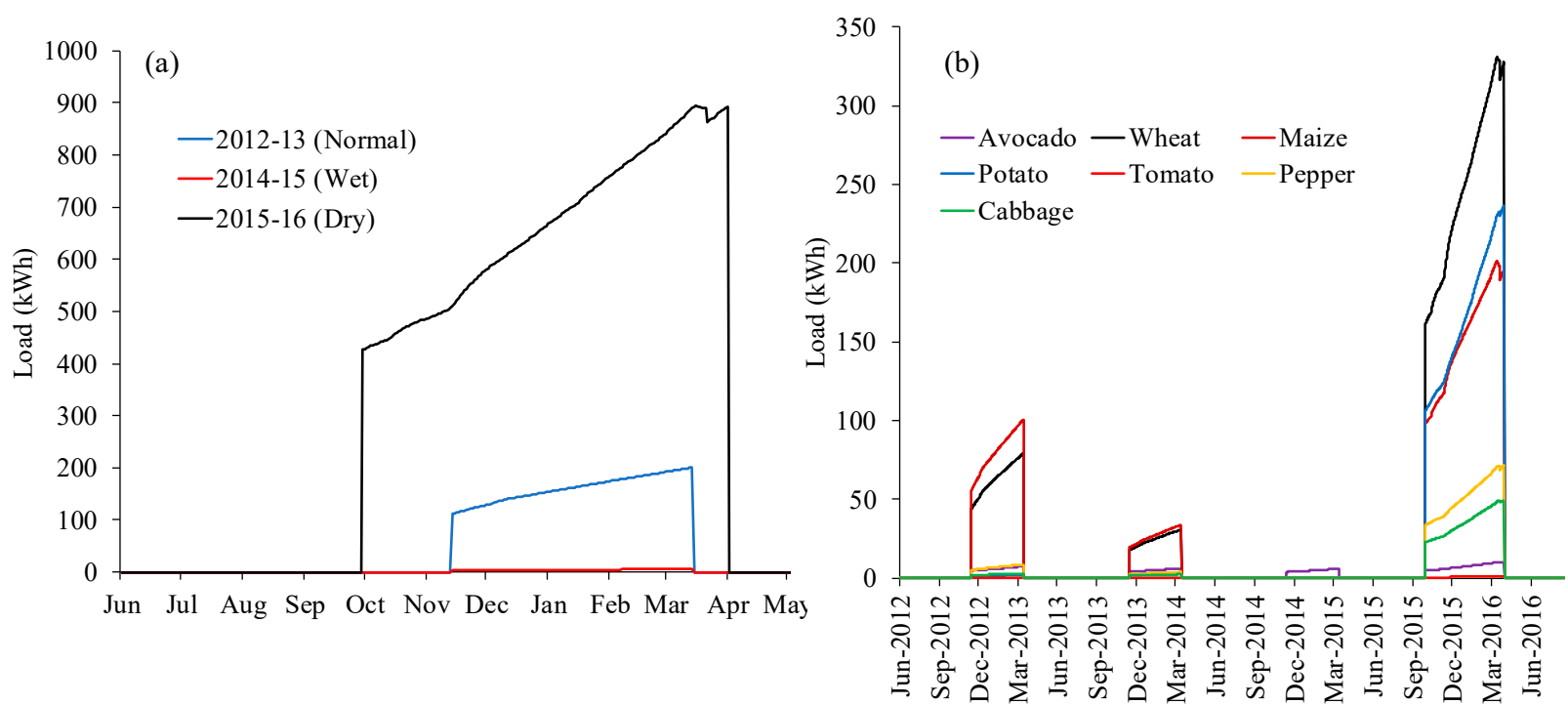

Figure 6. Loads estimated by Modflow-DSSAT based on supplemental groundwater irrigation, given a dynamic groundwater table in pumping locations, for (a) three cases of weather conditions, and (b) various crops. 


\subsection{Electricity Demand}

The electrical power demand was calculated based on a community size of 1000 households and certain community irrigation pumping loads. To optimize the microgrid design and simulate the expected load schedule, we created seven electrical load time slots over $24 \mathrm{~h}$. We modeled the household electrical loads with four load scenarios. Each scenario had a base load assigned to each household and consisted of five scheduled loads: electric stove cooking, LED lighting, smartphone charging, use of a small TV (15"), and use of a clock radio. Scenario 1 consisted of the base load and had a household average load of $363 \mathrm{kWh}$ per year. Ref [78] has determined that electrified urban households consume an average of $231 \mathrm{kWh}$ a year and rural households $168 \mathrm{kWh}$ a year. Scenario 2 added a $4 \mathrm{~kW}$ injera baking load, two times a week for one hour, and increased the annual household consumption to $780 \mathrm{kWh}$ per year. In Scenario 3, we removed the injera baking load, while we kept the base load and added a 12-kW milling machine for community milling, once a month for each family. In this scenario the annual household consumption was reduced to $411 \mathrm{kWh}$ per year. Finally, in Scenario 4, we added the injera baking, while keeping the base load and the 12-kW milling machine for community milling. In this final scenario, the household annual consumption came to $826 \mathrm{kWh}$ per year.

We modeled the irrigation pumping loads at $10-28 \mathrm{~kW}$, setting motor load operation during the early morning hours (12 a.m. to 7 a.m.) to help minimize parasitic load losses. Setting operation in the early morning, when ambient temperatures are typically lower than during daylight hours, also helped reduce the amount of HVAC operating time for the battery energy storage system (BESS). The motor load level varied throughout the year to meet the needs during the dry season.

\subsection{The Microgrid}

A fundamental microgrid design constraint was to meet the electric power demand by utilizing 100 percent renewable energy resources with storage. HOMER was used as a tool to model the distributed energy resources (DERs) and storage with the four power demand scenarios and simulated the power demand, or electrical loads, as $\mathrm{kW}$ inputs in hourly time increments. Note that HOMER is a great tool to approximate the size and quantity of generation or storage resources required in a microgrid design. It does not, however, have the capability to model the transient and subtransient conditions required to ensure power system stability in a microgrid.

For each of the scenarios, we employed the same DER equipment as a design input into the model. The model results yielded different DER sizes depending on the electrical power demand requirements for each of the scenarios. We used two types of DERs and one storage system in the microgrid design; see also Figure 7. The commercial market offers a large selection of DER and storage systems, each with different performance profiles. We selected for our design the DER and storage equipment systems included in HOMER's library, selecting LONGi $350 \mathrm{~W}$ photovoltaic (PV) panels and a generic $40 \mathrm{~kW}$ hydrokinetic (HK) turbine to convert the natural resources to electrical power generation. To balance the power generation during times of low DER output, we selected Tesla Powerpack 2 battery energy storage system (BESS) units. The BESS and PV systems each had dedicated inverters represented by custom HOMER devices. We optimized the BESS inverter size based on the storage requirements for each scenario. Given the maximum load profile, we preselected the PV inverter size at $300 \mathrm{~kW}$ for all scenarios. In a more detailed design, the PV inverter size would be determined by the PV supplier. 


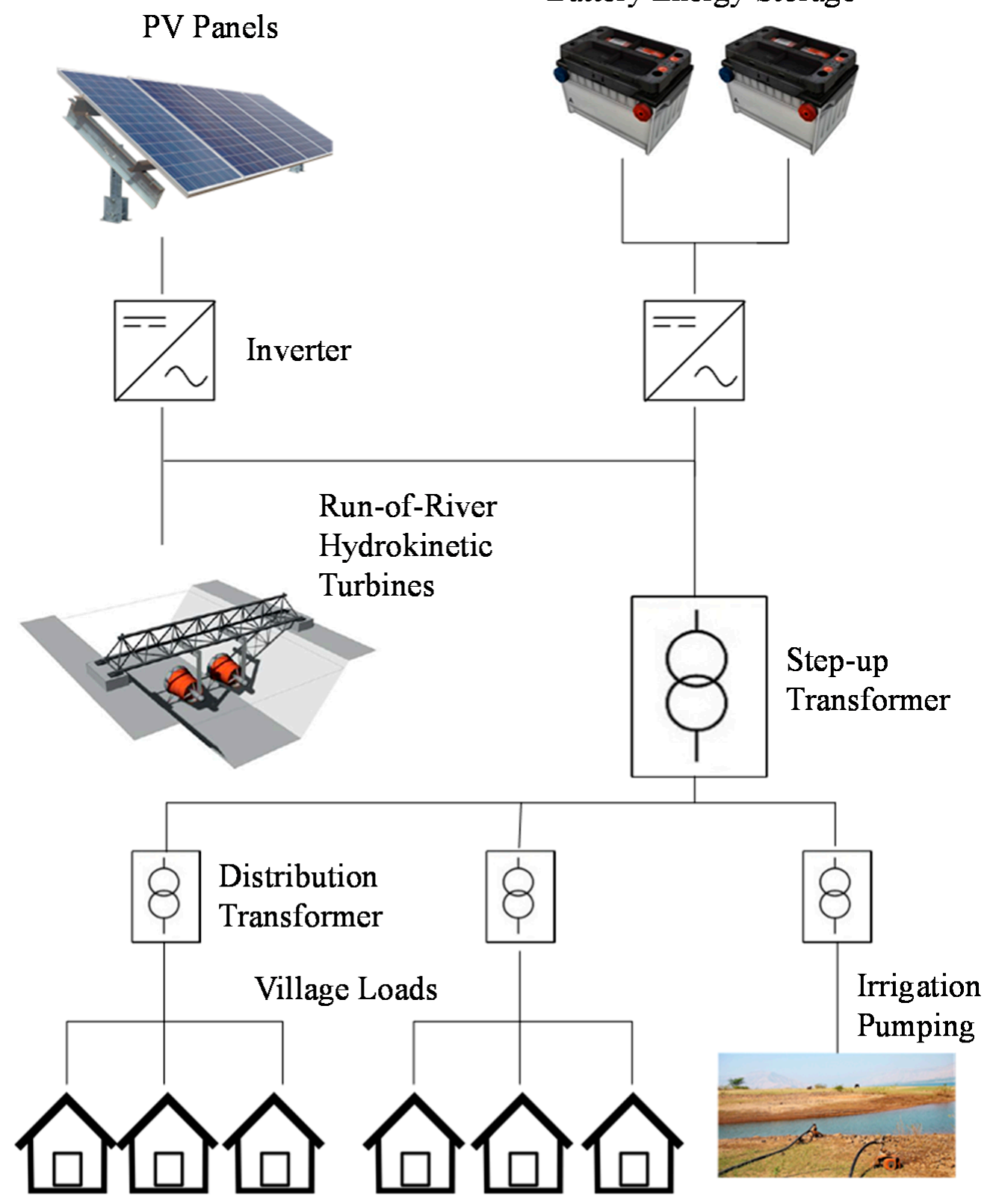

Figure 7. Proposed microgrid design for Kudmi kebele (Simple 1-Line), encapsulating all major system components.

Very few power distribution systems in the world can operate without power outages and HOMER accounts for this by allowing their inclusion in the design phase. Additionally, scheduled outages in remote and off-grid areas can reduce costs as well as system complexity. As a result, for the purposes of this study, we selected and modeled 5 percent, 8 percent, and 10 percentage outages for each scenario. Based on the scenario loads and outage case, the software optimized the number of DER assets, converging on the most cost-effective design. For each microgrid architecture, one component in the design did not change in size; the PV inverter at $300 \mathrm{~kW}$ remained constant. Note that, in an actual implementation of a microgrid, the acceptable percentage of outages would be decided by village leaders and stakeholders.

In the first scenario, which consisted of the household base load and irrigation pumping loads, the consumption profile in the 5 percent outage case was $401,822 \mathrm{kWh} / \mathrm{yr}$. To satisfy the load requirements, the model results yielded a microgrid system architec- 
ture that included the PV inverter, $446 \mathrm{~kW}$ of PV panels, five Tesla Power Packs with a $225 \mathrm{~kW}$ BESS inverter, and no HK DERs. The PV DERs combined for a total production of $486,416 \mathrm{kWh} / \mathrm{yr}$. The BESS throughput, or the amount of energy cycled through the storage bank, was 241,076 kWh/yr. The capital cost for this scenario's design was USD 12.3 million. Table 3 provides a summary of DER quantities and cost, including the 8 percent and 10 percent outage cases. As the table makes evident, an increase in the outage percentage led to a reduction in the PV panels and an increase in the hydropower usage. The battery needs were not affected significantly, yet the capital cost was reduced by approximately USD 2 million in both cases.

Table 3. Simulation results for the scenario including the approximated base load and electric stove cooking (i.e., Scenario 1).

\begin{tabular}{cccc}
\hline & \multicolumn{3}{c}{ Base Load and Electric Stove } \\
\hline Outage Percentages & $5 \%$ & $8 \%$ & $10 \%$ \\
\hline PV Panels $(\mathrm{kW})$ & 446.0 & 379.0 & 372.0 \\
\hline Tesla-BESS (Qty) & 5.0 & 4.0 & 4.0 \\
\hline Converter (kW) & 225.0 & 218.0 & 205.0 \\
\hline Hydrokinetic (Qty) & 0.0 & 8.0 & 4.0 \\
\hline Cap Cost (USD) & $12.3 \mathrm{M}$ & $10.5 \mathrm{M}$ & $10.3 \mathrm{M}$ \\
\hline
\end{tabular}

In Scenario 2, which consisted of the same loads as Scenario 1 with the addition of injera baking, the load consumption profile in the 5 percent outage case was increased to $895,749 \mathrm{kWh} / \mathrm{yr}$. Subsequently, HOMER yielded a microgrid system architecture that included significantly increased PV panels $(832 \mathrm{~kW})$ and three times more Tesla Power Packs (fifteen), a $199 \mathrm{~kW}$ BESS (with a throughput of 179,209 kWh/yr) inverter, and eight $40 \mathrm{~kW}$ HK hydro DERs, leading to a total production of 1,031,955 kWh/yr. Quite expectedly, the capital cost for this scenario was almost doubled to USD 24.2 million, with a consistent decrease of approximately USD 2 million for the 8 percent and 10 percent outage cases (see also Table 4). This last point proved that, regardless of the loads included, the relationship between capital cost and power outage percentage would remain constant. It is important to note the reduction in battery storage needs when the outage percentage increased in this scenario. A 3 percent increase almost halved the Tesla Power pack requirements, from fifteen to seven.

Table 4. Simulation results for the scenario including the approximated base load, electric stove cooking, as well as injera baking (i.e., Scenario 2).

\begin{tabular}{cccc}
\hline \multicolumn{4}{c}{ Base Load and Electric Stove + Injera Baking } \\
\hline Outage Percentages & $5 \%$ & $8 \%$ & $10 \%$ \\
\hline PV Panels (kW) & 832.0 & 826.0 & 817.0 \\
\hline Tesla-BESS (Qty) & 15.0 & 7.0 & 6.0 \\
\hline Converter (kW) & 199.0 & 271.0 & 246.0 \\
\hline Hydrokinetic (Qty) & 8.0 & 8.0 & 8.0 \\
\hline Cap Cost (USD) & $24.2 \mathrm{M}$ & $22.3 \mathrm{M}$ & $21.9 \mathrm{M}$ \\
\hline
\end{tabular}

For the third scenario, which included a $12-\mathrm{kW}$ milling machine along with the loads of Scenario 1, the load consumption profile in the 5 percent outage case reached $470,598 \mathrm{kWh} / \mathrm{yr}$. The microgrid system for this case included approximately the same combination of PV panels $(450 \mathrm{~kW})$ and Tesla Power Packs (five). The BESS inverter requirement was $199 \mathrm{~kW}$, with an increased amount of hydropower (eight $40 \mathrm{~kW}$ HK hydro DERs), which yielded a total production of $621,610 \mathrm{kWh} / \mathrm{yr}$ - more than 2.5 times the 
energy amount of Scenario 1. Yet, the capital cost for this design was USD 12.5 million (see also Table 5), showing that the inclusion of the socially beneficial milling machine, which led to a monetary savings of up to USD 9.70 per ton milled per year (see [79]) and notably increased the time available for engaging in other activities, did not induce any significant cost increases.

Table 5. Simulation results for the scenario including the approximated base load, electric stove cooking, as well as the use of communal milling (i.e., Scenario 3).

\begin{tabular}{cccc}
\hline \multicolumn{4}{c}{ Base Load and Electric Stove + Milling Machine } \\
\hline Outage Percentages & $5 \%$ & $8 \%$ & $10 \%$ \\
\hline PV Panels (kW) & 450.0 & 433.0 & 424.0 \\
\hline Tesla-BESS (Qty) & 5.0 & 4.0 & 4.0 \\
\hline Converter (kW) & 199.0 & 208.0 & 231.0 \\
\hline Hydrokinetic (Qty) & 8.0 & 4.0 & 4.0 \\
\hline Cap Cost (USD) & $12.5 \mathrm{M}$ & $11.9 \mathrm{M}$ & $11.6 \mathrm{M}$ \\
\hline
\end{tabular}

Finally, in Scenario 4, which included a 12-kW milling machine load and injera baking, the load consumption profile was the highest $(966,246 \mathrm{kWh} / \mathrm{yr}$ for the $5 \%$ outage case; see Table 6). Still, not all aspects of the design were significantly greater than in the rest of the scenarios. While the PV panels increased by $100 \mathrm{~kW}(938 \mathrm{~kW})$ in comparison to the second Scenario, the Tesla Power Packs were halved to seven, with a $212 \mathrm{~kW}$ BESS inverter and the same hydropower requirement. The total production reached 1,115,590 kWh/yr, with a capital cost of USD 25.1 million. Note, however, that the increase in the outage percentage did not play a role anymore (the capital cost was equivalent for all cases in Table 6), due to the significantly increased need for battery storage (twelve Tesla Power Packs for the 10 percent outage percentage case). Another interesting point is that, despite the inclusion of injera baking, the initial storage requirement was reduced to seven battery packs, due to the use of the milling machine, which made the utilization of solar power more efficient. This is quite important, since increased capacity to use both injera and milling is a significant step toward ensuring food security for the region.

Table 6. Simulation results for the scenario including the approximated base load, electric stove cooking, as well as injera baking and the use of communal milling (i.e., Scenario 4).

\begin{tabular}{cccc}
\hline \multicolumn{4}{c}{ Base Load and Electric Stove + Injera Baking and Milling Machine } \\
\hline Outage Percentages & $5 \%$ & $8 \%$ & $10 \%$ \\
\hline PV Panels (kW) & 938.0 & 934.0 & 892.0 \\
\hline Tesla-BESS (Qty) & 7.0 & 8.0 & 12.0 \\
\hline Converter (kW) & 212.0 & 244.0 & 309.0 \\
\hline Hydrokinetic (Qty) & 8.0 & 4.0 & 8.0 \\
\hline Cap Cost (USD) & $25.1 \mathrm{M}$ & $25.1 \mathrm{M}$ & $25.0 \mathrm{M}$ \\
\hline
\end{tabular}

\subsection{Social and Economic Effects}

Previous research efforts have identified the complex pathways by which electricity and appliance ownership lead to greater human well-being. An analysis conducted by the World Bank in Ethiopia ([45]) found that rural households that had recently acquired access to electricity had experienced several positive outcomes, including better indoor air quality, better lighting, reduced kerosene and battery consumption, less energy expenditure, better access to news, and better working conditions, among others. Based on brief field interviews with farmers and community members in Kudmi, as well as in Rim, a neighboring kebele, the study found most residents were interested in switching to the clean 
lighting alternatives made possible by electrification rather than use kerosene lamps, since the latter are expensive and accident-prone and can lead to severe health issues. All other alternative sources of lighting, such as hurricane lanterns, candles, and flashlights, can also be expensive, unreliable, or ineffective (see [45]). Clearly, lighting that originates from energy distributed by the microgrid could be highly beneficial. We can push this analysis further by applying an approach similar to that of [45], identifying the various pathways for positive impact. In addition to the other advantages already mentioned, electrification for lighting in our study area can improve education outcomes for children by extending the time available for study by 15 to 20 percent (see also [45]), while mobile phones, radios, and televisions open up a world of current information on markets, weather forecasts, child and reproductive health, and job opportunities.

During the fieldwork, conversations were held with two farmers who owned solarpowered irrigation systems implemented by the Agricultural Transformation Agency (ATA) project in the Abyot Fana kebele. Farmers and experts at the woreda agricultural office were given basic training on maintaining PV cells and tube wells and were equipped with spare parts after the system was established. Both farmers interviewed confirmed they were invested in tending and protecting the PV-driven irrigational system. They cleaned the PV panels with soft cloths, with one of them actually dedicating cloth to that single purpose, and both had put up wooden fences surrounding the PV arrays' domains. A complication mentioned by one of the farmers was that, after an accident that damaged certain system components (a wooden tank for water irrigation), he was required to pay for replacements from his own funds because the woreda office refused to provide them. This highlights the importance of designating the parties responsible for maintenance, repairs, and the purchase of sufficient replacement parts prior to installing any microgrid components in the kebele.

To determine what land might be available for PV arrays in Kudmi, a field interview was conducted with the kebele manager, who indicated several large plots of at least a few hectares each that are communally held. These common lands can be utilized with community consultation and approval. Since people are eager to have access to electric power, approval is anticipated.

While not everyone in the kebele is expected to be able to afford the same amount of electricity or the same electrical appliances, studies in Ethiopia suggest even the poorest households "value the purchase of new appliances"; this is supported by findings that 96.1 percent of rural households are willing to pay for a grid connection; see [45,80]. The same assessments showed that, after gaining access to electricity, only one in four households continued using kerosene for lighting, while a quarter of the families stopped using charcoal or wood for cooking (5 percent purchased an electric injera mitad). Most families, after expending funds on electricity and appliances, waited to save money for additional electricity and appliance purchases. As it enables them to acquire and use these amenities, the microgrid-produced energy will ensure the families can avoid contact with the hazardous substances and biomass associated with other fuel sources, which can cause chronic and active respiratory illnesses along with other health problems (see also $[47,81]$ ), while offering them the advantages of thermal efficiency and increased time to engage in activities other than collecting firewood; see, e.g., [82].

\subsection{Implementation and Interactions}

The general consensus about the interaction of local, state, and national governance structures with renewable energy dissemination and rural electrification is that government institutional policy and regulatory frameworks are important to its success. Specifically, policies should be implemented, first, to provide basic electricity supply to the approximate 55.7 percent of houses that have no or insufficient access to electricity and, second, to increase the use of clean-fuel electric stoves. Additionally, important is to reduce gender gaps in the ability to pay for electricity and cleaner cooking stoves ([80]). 
The most effective way to create and manage a microgrid in Ethiopia is through an electricity cooperative. An electricity co-op, such as the Electric Users' Association, is a group of electrical systems, typically for rural communities that are owned and regulated by consumers and not connected to the main grid. In Maji, for example, a kebele of 700 families in southwest Ethiopia, the National Rural Electric Cooperative Association International (NRECA) formed a co-op to provide homes with solar energy systems on lease-to-own agreement. As a result, families have been able to use electricity for light and devices such as phones, radios, and televisions at low cost and within a locally controlled, self-reliant, and financially sustainable microgrid. Before the installation of these systems, NRECA worked with the local community over months to build awareness and trust by educating the residents on the systems' functionality and benefits-as well as the inevitable challenges associated with them-and it continued to oversee the project after its completion to ensure the co-op maintained its serviceability and the community stayed engaged; see also [45].

As the case of Maji shows, the adoption of the microgrid must happen in stages. Once residents have access to electricity they can afford, they can begin purchasing electric water pumps for irrigation, as well as appliances such as lights, stoves, radios and TVs, and injeras, and they can charge other devices, such as mobile phones, at home. The next stage is the conferral of clear benefits by these devices and appliances on agriculture and the lifestyles of the kebele residents (see also [45,83]), which can be immediate and direct (for example, more light correlating to more study time for students) or long-term and indirect (such as higher educational achievements for students). To optimize further the microgrid's services and address local concerns, a third stage should involve the administration of a survey to ask about the appliances and processes households are powering because of the microgrid and the benefits and challenges they have experienced as a result.

Many households may have trouble purchasing electrical appliances or materials, either because they are unavailable in local stores or the households' income is insufficient (see, e.g., [45]). For this reason, it is important to encourage local vendors to buy and sell mostly those appliances that will be used frequently by electrified households, and at reasonable prices. As an example of the current price ranges, during one of the interviews in the area, one of the farmers claimed to have invested 1300 Ethiopian Birr (USD 35.50) to purchase electric wires, two lamps, and switches to connect in an outlet of a PV system, while irrigational pipes are sold for about 6 Ethiopian Birr (USD 0.03) per meter.

Moreover, to promote electricity conservation, the purchase of energy-saving appliances and devices, such as compact fluorescent lightbulbs, should be highly encouraged and incentives offered for their use. Note that some households may still prefer using less efficient appliances, such as incandescent bulbs, which are more adequate for their needs-for instance, by functioning even with voltage drops-and a balance needs to be maintained between electricity conservation and such household necessities, driven by the design specifications of the microgrid. Additionally, strategic communication to the community of the schedule of certain large household loads is important, not only to prevent potential disruptions of the energy distribution but also to raise the awareness of the population about the full capabilities of the microgrid, to make its use as advantageous as possible. One local farmer, for example, mentioned using electricity solely to power water pumps so as not to overload the system, where the manufacturer had indicated the system could generate enough electricity to power a TV, as well.

While this research effort focuses mostly on basic household needs, household businesses can also benefit from rural electrification. With electricity available to them, some households can engage in the production and selling of groceries and other retail goods (see also [45]), particularly in view of the increased and more stable crop yields brought to them by microgrid-driven irrigation. The additional income brought to rural residents by such household-based businesses will further contribute to the betterment of their livelihoods.

Overall, strategic pricing of the energy originating from the microgrid is vital. Costs have to be high enough to provide a return on the investment, while still allowing lowerincome families to have access to electricity. For a middle-income household (about USD 
470/year), an electricity fee of around 3 percent may not be a significant financial strain, but even a USD 75 fee imposes a significant financial burden on low-income households, since it amounts to over 40 percent of their total earnings. To address this, a gradual tariff should be implemented, with unit costs that correlate to the amount of electricity being utilized per household; see also [45].

\section{Conclusions}

In this study, we attempted to design and optimize a fully RE-based microgrid, with the goal of producing sufficient energy to meet the agricultural and societal needs of a kebele (Kudmi) in Ethiopia. To do so, we employed ECMWF's ERA5-Land climatic reanalysis dataset, along with CREST simulations of the water flow in nearby irrigational canals, for the last 20 years. Our analysis was supported by information and data retrieved by interviews and fieldwork in Kudmi, as well as in other kebele located in the Amhara region, and culminated in an assessment of the social and economic effects accompanied by considerations for a potential future implementation. The foregoing sociological observations encapsulate fairly pragmatic needs and habits of the local people, the actual crops cultivated in the region, the most frequently used and available appliances, as well as the cooking schedule followed by the average household. Consequently, we were able to formulate an energy demand plan so the simulations of the microgrid would be as realistic as possible. Note that the analysis pertaining to flow and irrigation requirements was based on typical hydrological years, as it did not include any extreme (dry or wet) cases, in which the irrigation demands would be overwhelming. The implementation of a microgrid system in such scenarios would require additional research and information on potential strategies to accommodate the respective needs.

We demonstrated four different scenarios of the potential functionality and service of the microgrid, accompanied by the corresponding capital costs. At this point, it should be highlighted that the goal was not to distinguish one prevailing scenario over the rest, but to capture various levels of potential social benefits. The designed microgrid would be harmless to the environment, as it would be based solely on RE, with its cost varying for different tolerance levels of scheduled outages (see also Section 4.3). The results made it evident (see also Tables 3-6) that the inclusion of a milling machine, which would benefit the community both socially and economically, would not induce any significant increase in cost. On the other hand, the incorporation of injera baking would double the capital cost, primarily because of the intensified need for battery storage. Yet, while the utilization of both injera baking and a milling machine would swell the cost, the scheduling of the milling process would reduce the energy storage requirements by half. This is quite important, considering that the use of both would ensure greater food security for the region, as well as opportunities for households to increase their incomes.

Considering that various farmers in Kudmi and other neighboring kebele are already invested in utilizing, maintaining, and protecting simple RE schemes (such as PV arrays and hand-made water mills) to support their agricultural and social activities, the microgrid would probably be well accepted by the community as a sustainable solution to their energy and agricultural needs. According to local officials, people would welcome the establishment of a sustainable energy source, with the microgrid installed in one of the large available communal areas. The supplied energy would be highly beneficial in a number of ways. People's health would benefit from the replacement of potentially harmful means of lighting (such as kerosene lamps) with electricity-based solutions, and the thorough cooking of meals made possible by the use of electric stoves would make food consumption much safer. Moreover, the academic performance and education of children could be enhanced by the prolongation of study hours via better lighting and the ensured access to widely available information via mobile phones, television, and radio. Ultimately, electrification could open job opportunities for the kebele residents, as agricultural production is boosted and tools and instruments, such as milling machines, are made available. With the higher 
yields, people could market part of their raw or processed crops for additional income, thus further upgrading their quality of living.

Certainly, a potential implementation of such a microgrid would require extended and in-depth investigations into the management of the venture, as well as the role and responsibilities of the involved parties and stakeholders. Continuous education of the kebele residents and woreda officials should take place both before and after the establishment of the microgrid so the community will stay engaged and derive the most possible benefit from the supplied energy by learning how to manage, maintain, and conserve it effectively. Following the installation and functioning of the RE system, further studies should focus on the social dynamics and new habits of local people, in view of further optimizing the performance of the microgrid and tailoring its service to the community's needs.

Author Contributions: Conceptualization, E.N.A.; methodology, S.E., J.P., F.K.K., M.Y., E.A., H.N., E.H. and E.N.A.; software, S.E., J.P., S.M., F.K.K. and M.Y.; validation, S.E., J.P., S.M., F.K.K., E.A., H.N., N.R., E.H. and E.N.A.; formal analysis, S.E., J.P., S.M., F.K.K., M.Y., E.A., H.N. and N.R.; investigation, S.E., J.P., S.M., F.K.K., M.Y., E.A., H.N. and N.R.; resources, E.N.A. and E.H.; data curation, S.E., J.P., S.M., F.K.K., M.Y., E.A., H.N. and N.R.; writing-original draft preparation, S.E., J.P., S.M., F.K.K., M.Y., E.A., H.N. and N.R.; writing-review and editing, S.E. and E.N.A.; visualization, S.E., J.P., S.M., F.K.K., M.Y., E.A., H.N. and N.R.; supervision, E.N.A. and E.H.; project administration, E.N.A., E.H. and S.E.; funding acquisition, E.N.A. All authors have read and agreed to the published version of the manuscript.

Funding: This research received no external funding.

Institutional Review Board Statement: Not applicable.

Informed Consent Statement: Not applicable.

Data Availability Statement: For the ERA5-Land data used in this study the reader is referred to: Muñoz Sabater, J. (2019) ERA5-Land hourly data from 1981 to present. Copernicus Climate Change Service (C3S) Climate Data Store (CDS). [accessed on 12 July 2020], doi: 10.24381/cds.e2161bac.

Acknowledgments: This study was supported by the Eversource Energy Foundation Environmental Clinic. The authors would also like to thank the Assistant Editor and two anonymous reviewers for their constructive comments and recommendations, which improved the quality of the present study.

Conflicts of Interest: The authors declare they have no known competing financial interests or personal relationships that could have appeared to influence the work reported in this paper.

\section{References}

1. Mohtar, R.H.; Daher, B. Water, Energy, and Food: The Ultimate Nexus. In Encyclopedia of Agricultural, Food, and Biological Engineering, 2nd ed.; CRC Press: Boca Raton, FL, USA, 2010; pp. 1-5. [CrossRef]

2. Markantonis, V.; Reynaud, A.; Karabulut, A.; El Hajj, R.; Altinbilek, D.; Awad, I.M.; Bruggeman, A.; Constantianos, V.; Mysiak, J.; Lamaddalena, N.; et al. Can the Implementation of the Water-Energy-Food Nexus Support Economic Growth in the Mediterranean Region? The Current Status and the Way Forward. Front. Environ. Sci. 2019, 7, 84. [CrossRef]

3. de Fraiture, C.; Wichelns, D. Satisfying future water demands for agriculture. Agric. Water Manag. 2010, 97, 502-511. [CrossRef]

4. Hoekstra, A.Y.; Mekonnen, M.M. The water footprint of humanity. Proc. Natl. Acad. Sci. USA 2012, 109, 3232-3237. [CrossRef]

5. Hoekstra, A.Y.; Wiedmann, T.O. Humanity's unsustainable environmental footprint. Science 2014, $344,1114-1117$. [CrossRef] [PubMed]

6. Rockström, J.; Falkenmark, M.; Karlberg, L.; Hoff, H.; Rost, S.; Gerten, D. Future water availability for global food production: The potential of green water for increasing resilience to global change. Water Resour. Res. 2009, 45. [CrossRef]

7. Rosegrant, M.W.; Ringler, C.; Zhu, T. Water for Agriculture: Maintaining Food Security under Growing Scarcity. Annu. Rev. Environ. Resour. 2009, 34, 205-222. [CrossRef]

8. Tarrass, F.; Benjelloun, M. The effects of water shortages on health and human development. Perspect. Public Health 2011, 132, 240-244. [CrossRef]

9. Matson, P.A.; Parton, W.J.; Power, A.G.; Swift, M.J. Agricultural Intensification and Ecosystem Properties. Science 1997, 277, 504-509. [CrossRef] [PubMed]

10. Pellegrini, P.; Fernández, R.J. Crop intensification, land use, and on-farm energy-use efficiency during the worldwide spread of the green revolution. Proc. Natl. Acad. Sci. USA 2018, 115, 2335-2340. [CrossRef]

11. Kebebe, E. Bridging technology adoption gaps in livestock sector in Ethiopia: A innovation system perspective. Technol. Soc. 2019, 57, 30-37. [CrossRef] 
12. Thornton, P.K. Livestock production: Recent trends, future prospects. Philos. Trans. R. Soc. B Biol. Sci. 2010, 365, 2853-2867. [CrossRef]

13. Noureldeen Mohamed, N. Water Energy Food Nexus. In Energy in Agriculture under Climate Change; SpringerBriefs in Climate Studies; Springer: Cham, Switzerland, 2020; pp. 47-59. [CrossRef]

14. Pelletier, N.; Audsley, E.; Brodt, S.; Garnett, T.; Henriksson, P.; Kendall, A.; Kramer, K.J.; Murphy, D.; Nemecek, T.; Troell, M. Energy Intensity of Agriculture and Food Systems. Annu. Rev. Environ. Resour. 2011, 36, 223-246. [CrossRef]

15. Chen, X.; Thorp, K.R.; Ouyang, Z.; Hou, Y.; Zhou, B.; Li, Y. Energy consumption due to groundwater pumping for irrigation in the North China Plain. Sci. Total Environ. 2019, 669, 1033-1042. [CrossRef]

16. Soto-García, M.; Martin-Gorriz, B.; García-Bastida, P.; Alcon, F.; Martínez-Alvarez, V. Energy consumption for crop irrigation in a semiarid climate (south-eastern Spain). Energy 2013, 55, 1084-1093. [CrossRef]

17. Amjath-Babu, T.; Krupnik, T.J.; Kaechele, H.; Aravindakshan, S.; Sietz, D. Transitioning to groundwater irrigated intensified agriculture in Sub-Saharan Africa: An indicator based assessment. Agric. Water Manag. 2016, 168, 125-135. [CrossRef]

18. Villholth, K.G. Groundwater irrigation for smallholders in Sub-Saharan Africa-A synthesis of current knowledge to guide sustainable outcomes. Water Int. 2013, 38, 369-391. [CrossRef]

19. Scott, C.A. Electricity for groundwater use: Constraints and opportunities for adaptive response to climate change. Environ. Res. Lett. 2013, 8, 035005. [CrossRef]

20. Mulugetta, Y. Energy in Rural Ethiopia: Consumption Patterns, Associated Problems, and Prospects for a Sustainable Energy Strategy. Energy Sources 1999, 21, 527-539. [CrossRef]

21. Koizumi, T. Biofuels and food security. Renew. Sustain. Energy Rev. 2015, 52, 829-841. [CrossRef]

22. Mehdi, B.J.; Slim, B.Y. The role of renewable energy and agriculture in reducing $\mathrm{CO}_{2}$ emissions: Evidence for North Africa countries. Ecol. Indic. 2017, 74, 295-301. [CrossRef]

23. Singh, A.K.; Poonia, S.; Santra, P.; Jain, D. Ensuring Energy and Food Security through Solar Energy Utilization. In Contemporary Environmental Issues and Challenges in Era of Climate Change; Springer: Singapore, 2020; pp. 199-218. [CrossRef]

24. United Nations. Sustainable Development Goals: Goal 7. Department of Economic and Social Affais, Sustainable Development. 2021. Available online: https://sdgs.un.org/goals/goal7 (accessed on 16 March 2021).

25. Alves, M.; Segurado, R.; Costa, M. On the road to $100 \%$ renewable energy systems in isolated islands. Energy 2020, 198, 117321. [CrossRef]

26. Francois, B.; Borga, M.; Creutin, J.; Hingray, B.; Raynaud, D.; Sauterleute, J. Complementarity between solar and hydro power: Sensitivity study to climate characteristics in Northern-Italy. Renew. Energy 2016, 86, 543-553. [CrossRef]

27. Schmidt, J.; Cancella, R.; Pereira, A.O. An optimal mix of solar PV, wind and hydro power for a low-carbon electricity supply in Brazil. Renew. Energy 2016, 85, 137-147. [CrossRef]

28. Erbato, T.T.; Hartkopf, T. Smarter Micro Grid for energy solution to rural Ethiopia. In Proceedings of the 2012 IEEE PES Innovative Smart Grid Technologies (ISGT), Washington, DC, USA, 16-20 January 2012. [CrossRef]

29. Fodhil, F.; Hamidat, A.; Nadjemi, O. Potential, optimization and sensitivity analysis of photovoltaic-diesel-battery hybrid energy system for rural electrification in Algeria. Energy 2019, 169, 613-624. [CrossRef]

30. Maleki, A.; Pourfayaz, F.; Rosen, M.A. A novel framework for optimal design of hybrid renewable energy-based autonomous energy systems: A case study for Namin, Iran. Energy 2016, 98, 168-180. [CrossRef]

31. Brandoni, C.; Bošnjaković, B. HOMER analysis of the water and renewable energy nexus for water-stressed urban areas in Sub-Saharan Africa. J. Clean. Prod. 2017, 155, 105-118. [CrossRef]

32. Alvial-Palavicino, C.; Garrido-Echeverría, N.; Jiménez-Estévez, G.; Reyes, L.; Palma-Behnke, R. A methodology for community engagement in the introduction of renewable based smart microgrid. Energy Sustain. Dev. 2011, 15, 314-323. [CrossRef]

33. Jimenez-Estevez, G.A.; Palma-Behnke, R.; Ortiz-Villalba, D.; Mata, O.N.; Montes, C.S. It Takes a Village: Social SCADA and Approaches to Community Engagement in Isolated Microgrids. IEEE Power Energy Mag. 2014, 12, 60-69. [CrossRef]

34. Rahmann, C.; Núñez, O.; Valencia, F.; Arrechea, S.; Sager, J.; Kammen, D. Methodology for Monitoring Sustainable Development of Isolated Microgrids in Rural Communities. Sustainability 2016, 8, 1163. [CrossRef]

35. Power Africa. Off-Grid Solar Market Assessment; US Agency of International Development (USAID): Washington, DC, USA, 2019; pp. 1-47.

36. Food and Agriculture Organization. Ethiopia at a Glance. FAO in Ethiopia. 2020. Available online: http://www.fao.org/ ethiopia/fao-in-ethiopia/ethiopia-at-a-glance/en/ (accessed on 20 May 2020).

37. Lewis, K. Understanding climate as a driver of food insecurity in Ethiopia. Clim. Chang. 2017, 144, 317-328. [CrossRef]

38. Ethiopia Ministry of Water for Irrigation and Electricity. Second Growth and Transformation National Plan for the Water Supply and Sanitation Sub-Sector; Ethiopia Ministry of Water for Irrigation and Electricity: Addis Ababa, Ethiopia, 2015; pp. 1-4.

39. Falchetta, G.; Pachauri, S.; Parkinson, S.; Byers, E. A high-resolution gridded dataset to assess electrification in sub-Saharan Africa. Sci. Data 2019, 6, 110. [CrossRef]

40. Fereres, E.; Orgaz, F.; Gonzalez-Dugo, V. Reflections on food security under water scarcity. J. Exp. Bot. 2011, 62, 4079-4086. [CrossRef] [PubMed]

41. Ethiopia National Planning Commission. Growth and Transformation Plan (GTP II), 2015/16 -2019/20; Ethiopia National Planning Commission: Addis Ababa, Ethiopia, 2016; Volume 1, pp. 1-2. 
42. Hirmer, S.; Guthrie, P. The benefits of energy appliances in the off-grid energy sector based on seven off-grid initiatives in rural Uganda. Renew. Sustain. Energy Rev. 2017, 79, 924-934. [CrossRef]

43. Karekezi, S.; Kithyoma, W. Renewable energy strategies for rural Africa: Is a PV-led renewable energy strategy the right approach for providing modern energy to the rural poor of sub-Saharan Africa? Energy Policy 2002, 30, 1071-1086. [CrossRef]

44. DANAS Electrical Engineering. Electric Enjera Mitad: Energy Efficiency Standards and Labeling. Available online: https:/ / www.viennaenergyforum.org/sites/default/ files/documents /Development\%20of\%20Energy\%20efficint\%20local\% 20bread\%20making\%20\%20MITAD\%20Ehiopia\%20Getahun\%20Moges.pdf (accessed on 1 April 2021).

45. Barnes, D.; Golumbeanu, R.; Diaw, I. Beyond Electricity Access: Output-Based Aid and Rural Electrification in Ethiopia; World Bank: Washington, DC, USA, 2016; pp. 1-118.

46. Lam, N.L.; Smith, K.R.; Gauthier, A.; Bates, M.N. Kerosene: A Review of Household Uses and their Hazards in Low- and Middle-Income Countries. J. Toxicol. Environ. Health Part B 2012, 15, 396-432. [CrossRef] [PubMed]

47. Khandker, S.R.; Barnes, D.F.; Samad, H. Welfare Impacts of Rural Electrification: Evidence from Vietnam; World Bank: Washington, DC, USA, 2009.

48. Gillard, R.; Oates, L.; Kasaija, P.; Sudmant, A.; Gouldson, A. Sustainable Urban Infrastructure for All: Lessons on Solar Powered Streetlights from Kampala and Jinja, Uganda; Coalition for Urban Transitions: Washing, DC, USA; London, UK, 2019 ; pp. 1-20.

49. MacDonald, M. Koga Irrigation Scheme Manual: Operation and Maintenance. Part A: General Procedures. Volume I; Ministry of Water Resources: Addis Ababa, Ethiopia, 2008.

50. Lijalem, G.A. Irrigation Performance Evaluation Using GIS and Remote Sensing, Case of Koga Irrigation Area, Upper Blue Nile Basin. Master's Thesis, Bahir Dar University, Bahir Dar, Ethiopia, 2018.

51. Muñoz Sabater, J. ERA5-Land Hourly Data from 1981 to Present. Copernicus Climate Change Service (C3S) Climate Data Store (CDS). 2019. Available online: https:/ / doi.org/10.24381/cds.e2161bac (accessed on 12 July 2020).

52. Wang, J.; Hong, Y.; Li, L.; Gourley, J.J.; Khan, S.I.; Yilmaz, K.K.; Adler, R.F.; Policelli, F.S.; Habib, S.; Irwn, D.; et al. The coupled routing and excess storage (CREST) distributed hydrological model. Hydrol. Sci. J. 2011, 56, 84-98. [CrossRef]

53. Reynolds, B. Variability and Change in Koga Reservoir Volume, Blue Nile, Ethiopia; Uppsala University: Uppsala, Sweden, 2013.

54. Khadim, F.K.; Dokou, Z.; Bagtzoglou, A.C.; Yang, M.; Lijalem, G.A.; Anagnostou, E. A numerical framework to advance agricultural water management under hydrological stress conditions in a data scarce environment. Agric. Water Manag. 2021. (under review).

55. Yang, M.; Wang, G.; Lazin, R.; Shen, X.; Anagnostou, E. Impact of planting time soil moisture on cereal crop yield in the Upper Blue Nile Basin: A novel insight towards agricultural water management. Agric. Water Manag. 2021, 243, 106430. [CrossRef]

56. Jones, J.W.; Antle, J.M.; Basso, B.; Boote, K.J.; Conant, R.T.; Foster, I.; Godfray, H.C.J.; Herrero, M.; Howitt, R.E.; Janssen, S.; et al. Toward a new generation of agricultural system data, models, and knowledge products: State of agricultural systems science. Agric. Syst. 2017, 155, 269-288. [CrossRef]

57. Jones, J.W.; Antle, J.M.; Basso, B.; Boote, K.J.; Conant, R.T.; Foster, I.; Godfray, H.C.J.; Herrero, M.; Howitt, R.E.; Janssen, S.; et al. Brief history of agricultural systems modeling. Agric. Syst. 2017, 155, 240-254. [CrossRef]

58. Jones, J.W.; Hoogenboom, G.; Porter, C.H.; Boote, K.J.; Batchelor, W.D.; Hunt, L.A.; Wilkens, P.W.; Singh, U.; Gijsman, A.J.; Ritchie, J.T. The DSSAT cropping system model. Eur. J. Agron. 2003, 18, 235-265. [CrossRef]

59. Yamazaki, D.; Ikeshima, D.; Tawatari, R.; Yamaguchi, T.; O’Loughlin, F.; Neal, J.C.; Sampson, C.C.; Kanae, S.; Bates, P.B. A high-accuracy map of global terrain elevations. Geophys. Res. Lett. 2017, 44, 5844-5853. [CrossRef]

60. Hautot, S.; Whaler, K.; Gebru, W.; Desissa, M. The structure of a Mesozoic basin beneath the Lake Tana area, Ethiopia, revealed by magnetotelluric imaging. J. Afr. Earth Sci. 2006, 44, 331-338. [CrossRef]

61. Kebede, S. Groundwater in Ethiopia: Features, Numbers and Opportunities; Springer Science \& Business Media: Addis Ababa, Ethiopia, 2012; ISBN 978-3-642-30390-6. [CrossRef]

62. Beck, H.E.; Van Dijk, A.I.J.M.; Levizzani, V.; Schellekens, J.; Miralles, D.G.; Martens, B.; De Roo, A. MSWEP: 3-hourly 0.25 global gridded precipitation (1979-2015) by merging gauge, satellite, and reanalysis data. Hydrol. Earth Syst. Sci. 2017, 21, 589-615. [CrossRef]

63. Huffman, G.J.; Bolvin, D.T.; Braithwaite, D.; Hsu, K.L.; Joyce, R.J.; Kidd, C.; Nelkin, E.J.; Sorooshian, S.; Stocker, E.F.; Tan, J.; et al. Integrated Multi-satellite Retrievals for the Global Precipitation Measurement (GPM) Mission (IMERG). In Satellite Precipitation Measurement; Levizzani, V., Kidd, C., Kirschbaum, D., Kummerow, C., Nakamura, K., Turk, F., Eds.; Advances in Global Change Research; Springer: Cham, Switzerland, 2020; Volume 67, pp. 343-353. [CrossRef]

64. Lazin, R.; Shen, X.; Koukoula, M.; Anagnostou, E. Evaluation of the Hyper-Resolution Model-Derived Water Cycle Components Over the Upper Blue Nile Basin. J. Hydrol. 2020, 590, 125231. [CrossRef]

65. Dokou, Z.; Khadim, F.K.; Zhou, W.; Flamig, Z.; Moges, M.; Tilahun, S.; Azage, M.; Moges, S.; Li, B.; Mellor, J.; et al. Citizen Science at the Source of the Blue Nile: Promoting Public Participation in Science for Ensuring Food and Water Security in Ethiopia. 2019. Available online: https:/ / pire.engr.uconn.edu/wp-content/uploads/sites/2414/2019/01/Poster_AGU2018_Dokou-FINAL.pdf (accessed on 1 April 2021).

66. Koch, F.D. Avocado Grower's Handbook, 1st ed.; Bonsall Publications: Bonsall, CA, USA, 1983; ISBN 0-9675198-0-2.

67. CSA. Agricultural Sample Survey. Stat. Bull. 2016, 1, 1-111.

68. Yang, M.; Wang, G.; Ahmed, K.F.; Adugna, B.; Eggen, M.; Atsbeha, E.; You, L.; Koo, J.; Anagnostou, E. The role of climate in the trend and variability of Ethiopia's cereal crop yields. Sci. Total Environ. 2020, 723, 137893. [CrossRef] 
69. Niswonger, R.G.; Prudic, D.E.; Regan, R.S. Documentation of the unsaturated-zone flow (UZF1) package for modeling unsaturated flow between the land surface and the water table with MODFLOW-2005. In U.S. Geological Survey Techniques and Methods; USGS: Reston, VA, USA, 2006.

70. Khadim, F.K.; Dokou, Z.; Lazin, R.; Moges, S.; Bagtzoglou, A.C.; Anagnostou, E. Groundwater modeling in data scarce aquifers: The case of Gilgel-Abay, Upper Blue Nile, Ethiopia. J. Hydrol. 2020, 590, 125214. [CrossRef]

71. Bal, S.K.; Mukherjee, J.; Choudhury, B.U.; Dhawan, A.K. Advances in Crop Environment Interaction; Springer Nature Singapore Pte Ltd.: Singapore, 2018. [CrossRef]

72. Lambert, T.; Gilman, P.; Lilienthal, P. Micropower system modeling with Homer. In Integration of Alternative Sources of Energy; Farret, F.A., Simões, M.G., Eds.; John Wiley \& Sons: Hoboken, NJ, USA, December 2005; ISBN 0471712329.

73. Bahramara, S.; Moghaddam, M.P.; Haghifam, M. Optimal planning of hybrid renewable energy systems using HOMER: A review. Renew. Sustain. Energy Rev. 2016, 62, 609-620. [CrossRef]

74. Dawood, F.; Shafiullah, G.; Anda, M. Stand-Alone Microgrid with 100\% Renewable Energy: A Case Study with Hybrid Solar PV-Battery-Hydrogen. Sustainability 2020, 12, 2047. [CrossRef]

75. Ajayi, C.; Oyawale, F.; Afolalu, S.A. Optimization and Performance Evaluation of Blender-Hammer Mill. J. Phys. Conf. Ser. 2019, 1378, 032023. [CrossRef]

76. Duffie, J.A.; Beckman, W.A. Solar Engineering of Thermal Processes, 2nd ed.; Wiley: New York, NY, USA, $1991 ;$ ISBN 100471510564.

77. Chow, V.T. Open-Channel Hydraulics; McGraw-Hill: New York, NY, USA, 1959; 680p, ISBN 9780070107762.

78. Mondal, A.H.; Bryan, E.; Ringler, C.; Mekonnen, D.; Rosegrant, M. Ethiopian energy status and demand scenarios: Prospects to improve energy efficiency and mitigate GHG emissions. Energy 2018, 149, 161-172. [CrossRef]

79. Borgstein, E.; Wade, K.; Mekonnen, D. Capturing the Productive Use Dividend: Valuing the Synergies between Rural Electrification and Smallholder Agriculture in Ethiopia; Rocky Mountain Institute: Basalt, CO, USA, 2020.

80. Padam, G.; Rysankova, D.; Portale, E.; Koo, B.; Keller, S.; Fleurantin, G. Ethiopia beyond Connection: Energy Access Diagnostic Report Based on the Multi-Tier Framework; World Bank: Washington, DC, USA, 2018; pp. 1-64.

81. Adem, K.D.; Ambie, D.A.; Arnavat, M.P.; Henriksen, U.B.; Ahrenfeldt, J.; Thomsen, T.P. First enjera baking biomass gasifier stove to reduce indoor air pollution, and fuel use. Aims Energy 2019, 7, 227-245. [CrossRef]

82. Alemayehu, Y.A. Status and Benefits of Renewable Energy Technologies in the Rural Areas of Ethiopia: A Case Study on Improved Cooking Stoves and Biogas Technologies. Int. J. Renew. Energy Dev. 2015, 4, 103-111. [CrossRef]

83. IEG (Independent Evaluation Group). The Welfare Impact of Rural Electrification: A Reassessment of the Costs and Benefits; Impact Evaluation Report; World Bank: Washington, DC, USA, 2008. 